\title{
Annual Report for 1972
}

Continuing its upward trend, membership finished the year at 3229. Of the 422 new members recruited, 151 were overseas, and there are now FPS members in 87 countries. There were 34 deaths and 219 resignations or deletions. The year also saw 25 more people becoming Benefactors and four new life memberships.

\section{Oryx $100 \%$ Fund}

In its second year of operation the Oryx 100\% Fund again proved the value of, and need for, a source of funding able to provide relatively small amounts at short notice. Donations totalling £3999 were received during the year, including $£ 1971$ earmarked. In April Council decided to contribute a matching sum from the Society for all unearmarked gifts up to a total of $£ 5000$ and at the end of the year $£ 2632$ had been so designated. $£ 6057$ was paid out of the Fund to the 27 projects as listed in the audited account of the Fund on page 142. The endangered animals helped by the Fund included marine turtles, the Asiatic lion, Zanzibar red colobus, mountain gorilla, Iriomote cat and the small whales. Countries involved included Colombia. Comoros Islands, Costa Rica, Ethiopia, India, Japan, Kenya, Malawi, Malaysia, Mozambique, Nepal, Rwanda, Seychelles, Taiwan and Zanzibar. From the Society's funds, $£ 1000$ of an anonymous donation was set aside as an Endangered Species Fund and $£ 288$ was paid out during the year for the compilation of reports on this subject, and by way of travel grants in connection with it.

\section{Legacies and donations}

A further instalment of $£ 500$ was received from the late $\mathrm{Mr} \mathrm{J}$. S. Douglas and also $£ 2000$ from the late Mrs. Grace Soward and $£ 100$ from the late Miss Hilda Bennett. Generous donations included $£ 200$ from $\mathrm{Mr}$ F. M. Johnson and $£ 100$ each from the Ernest Kleinwort Charitable Trust and the St. Katharine's Fund. Anonymous donations of $£ 2000$ (with a promise of two more annual grants of the same sum) and $£ 100$ were also received. The Society is extremely grateful for the very substantial anonymous donation and promise, which has enabled it to support several urgent endangered species projects. We are most grateful to the Bournemouth Natural History Society for the donation of $£ 121$ raised at its showing of The Last of the Wild and to Mr John Aspinall for allocating $£ 200$ to us from proceeds of the Royal Albert Hall Wildlife Rally.

\section{The Society's Wildlife Tours}

At the beginning of the year a second party visited Argentina and Brazil, this time under the leadership of Mr Maurice Earnshaw. In July, Oryx Tour No. 14, led by Dr David Jenkins, visited Zambia and Botswana, including the Kafue and Chobe parks, Blue Lagoon and the Victoria Falls. 


\section{International Meetings}

The Hon. Secretary and Editor represented the Society at the 11 th General Assembly of IUCN at Banff, Canada in September and following immediately after this the 2nd World National Parks Conference, held in the Yellowstone and Grand Teton Parks in America. They also attended two meetings of the Survival Service Commission, at Jersey in April and at Banff in September. The Hon. Secretary represented the Society at the 24th meeting of the International Whaling Commission, held in London in June and at the Environmental Forum which ran parallel to the Stockholm United Nations Conference on the Human Environment in the same month.

\section{Representation on Other Bodies}

Representation of the Society on other bodies continued to be as set out in the 1971 Annual Report except that Lord Medway replaced Lady Medway on the Council of the Federation of Zoological Gardens of Great Britain and Ireland.

\section{Arabian Oryx Herd}

The Arabian oryx herd at Phoenix Zoo, Arizona, increased from 30 at the beginning of the year to 34 at the end: 17 male and 17 female, of which 13, seven males and six females, belong to the FPS. Two animals died during the year and six were born. One male, the FPS-owned Jack, was exchanged with Los Angeles Zoo for a female, and six animals were sent to the San Diego Zoo as part of the policy to disperse the herd (see page 5).

\section{Meetings of the Society}

A record number of members and friends (350) attended the Annual General Meeting on June 29th, which was addressed by the Rt. Hon. Peter Walker, M.P., at that time Secretary of State for the Environment, and the BBC film Europe, a Continent Fit to Live in shown after an introduction by Richard Brock. On December 6th, Lord Zuckerman, Secretary of the Zoological Society of London and a Vice-President of the Society spoke on the role of zoos in conservation and the film Nakuru was shown through the kindness of Mr Aubrey Buxton and Anglia Television. Wine and cheese suppers were held at both meetings and the Zoo Meeting rooms were filled to capacity on both occasions. The successful series of film shows at the New Gallery cinema ended in March with another showing of The Last of the Wild.

\section{Conference on the Breeding of Endangered Species}

The first three days of May saw the staging in Jersey of an international conference on the captive breeding of endangered species and its role in their survival. This highly successful and valuable conference, organised jointly by the FPS and the Jersey Wildlife Preservation Trust, attracted nearly 300 conservationists and zoo men, among them 80 members of the Society. A highlight of 
the proceedings was the presentation by our President Lord Willingdon of a pair of Indian lion cubs to the Jersey zoo. It is hoped that these lions, purchased from the Junagadh zoo with the aid of an anonymous, earmarked grant to the Oryx 100\% Fund, will form a breeding nucleus of this highly endangered cat. We are most grateful for Air India's generous contribution in transporting the lions from India to Britain.

\section{Kingfisher}

The conservation news service formerly provided by the magazine Kingfisher, edited by Richard Fitter, is being continued in Oryx, further adding to the status of this as a leading conservation journal in the world. Oryx publication dates have been moved forward one month to January, May and September, December having proved an inconvenient month. As a result only two issues actually appeared in 1971, May and September, the second, however, being an enlarged issue.

\section{Film Library}

$22 \mathrm{I}$ bookings were made in the year. The BBONT (Berks, Bucks and Oxon Naturalists' Trust) film Wildlife for the Future was bought and The Uganda Kob and The Peace Game added to the library through the generosity of the Smithsonian Institution and $\mathrm{Dr}$ Helmut Buechner and the South African Tourist Corporation respectively.

\section{Christmas and Other Sales}

Almost 41,000 Christmas cards were sold, a slight drop on last year. We are most grateful to David Shepherd for allowing us to use his study of zebras, African Children, and to the picture's owner, $\mathrm{Mr}$ Bill Stremmel, and also to Keith Shackleton for his exciting picture of humpback whales which he drew specially for our other new card. A new Society tie design, in crimplene and bearing a single oryx head emblem worked in two colours, joined the range of popular gifts for members.

\section{The Zoological Society of London}

The Society is once more extremely grateful to the Zoological Society of London, both for providing our office accommodation and for the help and kindness extended to us during the year. 